\title{
Analysis of Wettability and Surface-Roughness of Titanium Grade 2 in Milling Process
}

\author{
Rifky Yusron ${ }^{1 *}$, AM. Mufarrih'², Saiful Arif ${ }^{2}$, Nanang Qosim² and Zakki Emzain ${ }^{2}$ \\ ${ }^{1}$ Department of Mechanical Engineering, University of Trunojoyo Madura, 69162 Bangkalan, Indonesia \\ ${ }^{2}$ Mechanical Engineering Department, Malang State of Polytechnic, 65141 Malang, Indonesia
}

\begin{abstract}
Titanium Grade 2 is a material that is widely applied in biomedical implant materials. Titanium Grade 2 has a good corrosion resistance and good biocompatibility in the body. However, due to the low thermal conductivity, it is necessary to select the appropriate machining parameter in order to produce a good surface roughness value. The purpose of this study was to determine the surface characteristics of Titanium Grade 2 which include wettability and surface roughness on milling process. The research design used the full factorial L9 method, with 2 factors and 3 levels. The spindle speed variable has a p-value of 0.039 and the feeding speed variable has a p-value of 0.025 . This shows that the two independent variables have a significant effect on the surface roughness response. The lowest surface roughness can be achieved by setting the spindle rotation at $700 \mathrm{rpm}$ and the feed speed at $25 \mathrm{~mm} / \mathrm{min}$. All specimens showed contact angle measurement results below $90^{\circ}$, which means hydrophilic. Titanium Grade 2 material with this milling machining process can be used as an alternative to semi-permanent implant fabrication methods such as maxillofacial bone implants, bones of the fingers and toes, and others.
\end{abstract}

Keywords: Factorial, Milling, Surface roughness, Titanium, Wettability

\section{Introduction}

The use of titanium biomaterial-based implant devices is quite widely applied in orthopaedic surgery and dentistry. Pure titanium and its alloys have properties that meet more requirements as implant materials than other metals. Pure titanium and its alloys have better biocompatibility and biomechanical properties than other metals and are biologically inert, and have very high corrosion resistance, which can spontaneously form a $\mathrm{TiO} 2$ layer on the surface [1], [2]. These advantages make titanium preferable to be developed as an implant material than other metals [3].

In addition to being free from cytotoxic elements, the performance of the implant is also shown by the interaction mechanism between the implant material and the surrounding tissue[4]. The initial interaction between the implant material and the biological environment is influenced by surface properties that regulate the number and quality of cell adhesion to the implant surface so that cells or tissues can develop [5], [6]. This interaction mechanism occurs at the implant interface with living tissue in the body [7]. Several research results that examine the interaction of the interface between the implant and the surrounding living tissue inform that the topography and surface roughness, chemical composition, surface energy, and the oxide layer on the surface of the implant material greatly determine the performance of the implant in the body tissues so that osseointegration occurs, or in other words. the surface of the implant material must be bioactive and biocompatible [8].

The rapid development of research has been carried out which focuses on surface engineering of implants based on pure titanium biomaterials and their alloys. In addition, surface roughness is one of the critical quality characteristics for the final product of the machining process. The surface roughness of a machining product can affect several product functions such as surface friction, heat transfer, the ability to spread lubrication and coating [9], [10].

Surface roughness is a critical quality indicator for surface quality, as well as being the most important parameter for measuring the surface quality of a machining product [11]. Surface roughness can affect the function of a product such as surface friction, heat transfer, the ability to spread lubrication and coating [12], [13]. Machinability of a material is determined by several criteria such as tool life, tool wear, cutting force, cutting temperature, surface conditions, and bur height [14]. According to titanium is a material that is difficult to mill, this is due to the poor thermal conductivity of the material so that during the machining process at high temperatures causes plastic deformation of the tool and

\footnotetext{
* Corresponding author : rifky.myusron@trunojoyo.ac.id
} 
increased chemical reactivity produced in the cutting zone[15].

Based on the things that have been described, it is necessary to conduct research on the surface characteristics of titanium produced from milling machining for applications in the medical field.

\section{Method}

This research is an experimental type of research, which aims to determine the causal interaction between variables by varying the process parameters. The setting of the CNC milling machine process parameters is adjusted to the machine's capabilities and refers to previous research. Tools, materials, experimental design and data analysis can be explained as follows.

\subsection{Tools and materials}

The machine used in this research is the DAHLIH CNC milling machine. The chisel used is an HSS end mill with a diameter of $17 \mathrm{~mm}$. The Dahlih CNC machine is shown in Figure 1. Titanium grade 2 with a diameter of $16 \mathrm{~mm}$ and a length of $40 \mathrm{~mm}$ was used in this study. Titanium grade 2 has a tensile strength of $358 \mathrm{Mpa}$, a yield strength of $285 \mathrm{Mpa}$ and an elongation of $33 \%$. The milling process is carried out by dry machining without coolant. The value of the surface roughness of the milled workpiece was measured using the Mitutoyo Surftest Sj-210.

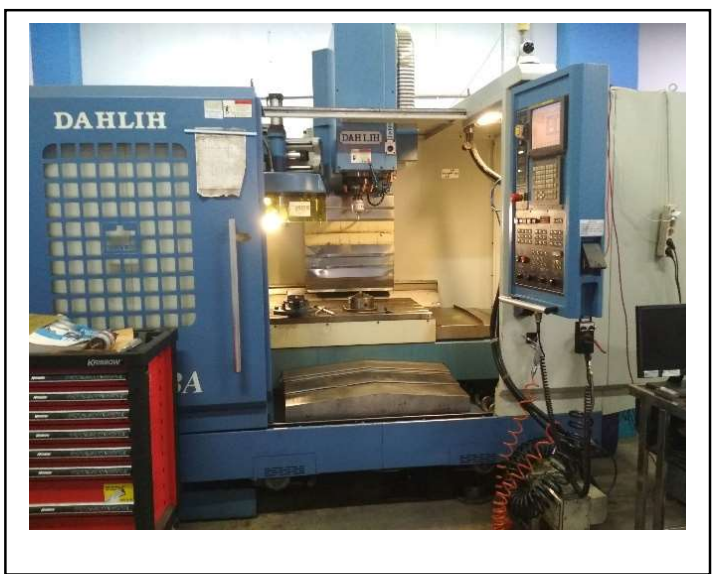

Fig. 1 Milling Machine

\subsection{Experimental Design}

The setting of the $\mathrm{CNC}$ milling machine process parameters adjusts to the machine's capabilities and refers to previous research. Table 1 shows the levels of spindle speed and feed speed used in this study.

Setting the process parameters using the Taguchi orthogonal array L9 method. The Taguchi method is used to study variables and their interactions which can be carried out using small amounts of experiments. The experimental design is shown in Table 2.
Table 1. Process parameters and levels.

\begin{tabular}{|c|c|c|}
\hline $\begin{array}{c}\text { Parameter } \\
\text { Level }\end{array}$ & $\begin{array}{c}\text { Spindel } \\
\text { Speed (n) }\end{array}$ & $\begin{array}{c}\text { Feeding } \\
\text { Speed }\left(\mathbf{V}_{\mathbf{j}}\right)\end{array}$ \\
\hline Level 1 & $500 \mathrm{rpm}$ & $25 \mathrm{~mm} / \mathrm{min}$ \\
\hline Level 2 & $700 \mathrm{rpm}$ & $50 \mathrm{~mm} / \mathrm{min}$ \\
\hline Level 3 & $900 \mathrm{rpm}$ & $75 \mathrm{~mm} / \mathrm{min}$ \\
\hline
\end{tabular}

Table 2. Process parameters and levels.

\begin{tabular}{|c|c|c|}
\hline Speciment & $\mathbf{n}(\mathbf{r p m})$ & $\mathbf{V}_{\mathbf{j}}(\mathbf{m m} / \mathbf{m i n})$ \\
\hline 1 & 500 & 25 \\
\hline 2 & 500 & 50 \\
\hline 3 & 500 & 75 \\
\hline 4 & 700 & 25 \\
\hline 5 & 700 & 50 \\
\hline 6 & 700 & 75 \\
\hline 7 & 900 & 25 \\
\hline 8 & 900 & 50 \\
\hline 9 & 900 & 75 \\
\hline
\end{tabular}

\section{Results}

The surface roughness of Titanium grade 2 was measured on three surface areas using a Mitutoyo surface roughness tester, then the results were averaged to obtain the average surface roughness value of each specimen. Table 3 shows the results of surface roughness measurements.

Table 3. Surface roughness measurement.

\begin{tabular}{|c|c|c|c|c|}
\hline $\begin{array}{c}\text { Specime } \\
\text { nt }\end{array}$ & $\begin{array}{c}\text { Surface } \\
\text { roughne } \\
\text { ss 1 }\end{array}$ & $\begin{array}{c}\text { Surface } \\
\text { roughne } \\
\text { ss 2 }\end{array}$ & $\begin{array}{c}\text { Surface } \\
\text { roughne } \\
\text { ss 3 }\end{array}$ & $\begin{array}{c}\text { Average } \\
\text { Surface } \\
\text { roughne } \\
\text { s }\end{array}$ \\
\hline 1 & 0,565 & 0,565 & 0,565 & 0,565 \\
\hline 2 & 0,651 & 0,646 & 0,632 & 0,643 \\
\hline 3 & 1,253 & 1,242 & 1,231 & 1,242 \\
\hline 4 & 0,432 & 0,436 & 0,428 & 0,432 \\
\hline 5 & 0,512 & 0,512 & 0,512 & 0,512 \\
\hline 6 & 0,772 & 0,768 & 0,797 & 0,779 \\
\hline 7 & 0,955 & 0,965 & 0,954 & 0,958 \\
\hline 8 & 0,824 & 0,823 & 0,825 & 0,824 \\
\hline 9 & 1,184 & 1,211 & 1,181 & 1,192 \\
\hline
\end{tabular}

The graph of the surface roughness value is shown in Figure 2. 


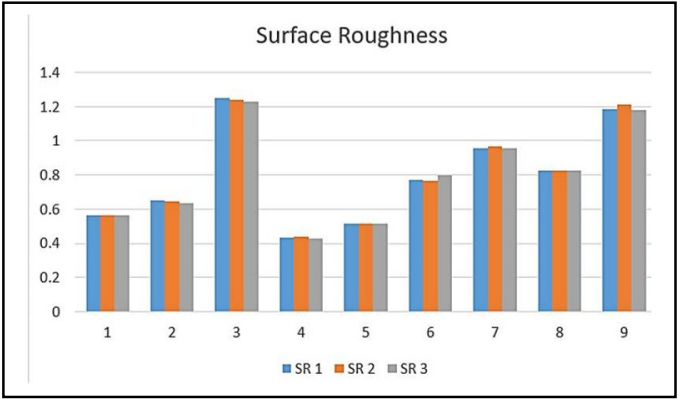

Fig. 2 Surface roughness plotting

Based on Figure 2, it can be seen that the range of surface roughness values of the three areas measured for each specimen is not much different. This shows that the milling process has been conducted properly.

\section{Discussion}

\subsection{Analysis of Process Parameters on Surface Roughness}

To find out whether the spindle speed and feed speed have an effect on the surface roughness value of the titanium grade 2 milled workpiece, an ANOVA (Analysis of variance) analysis was performed. ANOVA conditions can be done if the residuals meet three assumptions: identical, independent and normally distributed.

\subsubsection{Identical assumption test}

Identical assumptions can be met if the residuals do not form a certain pattern and are scattered randomly around the zero price. The results of the identical assumption test are shown in Figure 3. below.

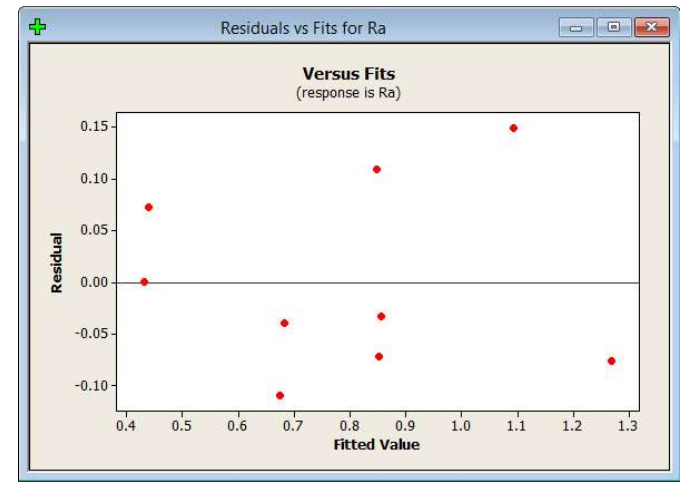

Fig 3. Plot of residual versus fitted values for Ra

The identical assumption test is shown in Figure 3. It shows that the residuals do not form a certain pattern and are randomly distributed around the zero price, so that the identical assumptions have been met. Normal Distribution Test
Normal distribution test was performed using Kolmogorov-Smirnov. The hypotheses used are:

H0 : Residual is normally distributed

H1 : Residual is not normally distributed

$\mathrm{H} 0$ is rejected if the p-value is less than 0.05 .

Based on Figure 4 can be obtained p-value of $>$ 0.150 , this value is greater than 0.05 . The conclusion of the hypothesis is that $\mathrm{H} 0$ is accepted. This means that the residual has met the requirements of a normal distribution.

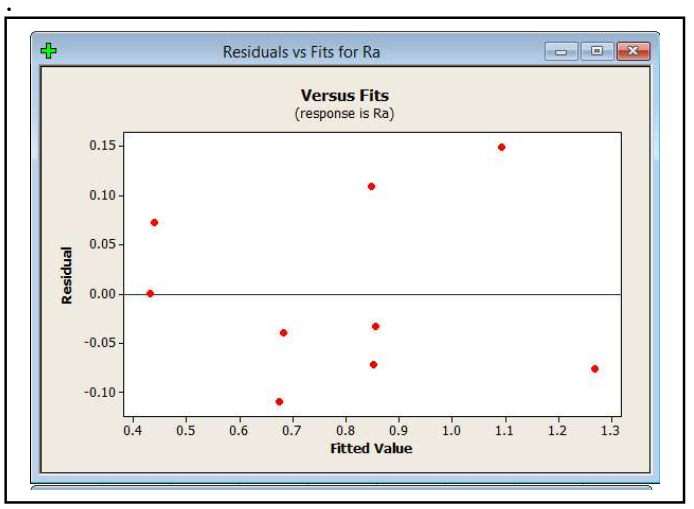

Fig. 4 Plot of residual versus fitted values for Ra

The identical assumption test is shown in Figure 3. It shows that the residuals do not form a certain pattern and are randomly distributed around the zero price, so that the identical assumptions have been met.

\subsubsection{Independent assumption test}

Independent assumption test is done by using auto correlation function (ACF). Based on the ACF plot shown in Figure 4, it can be seen that there is no ACF value in each lag that is outside the interval limit. This proves that there is no correlation between the residuals, so that the independent assumption is fulfilled.

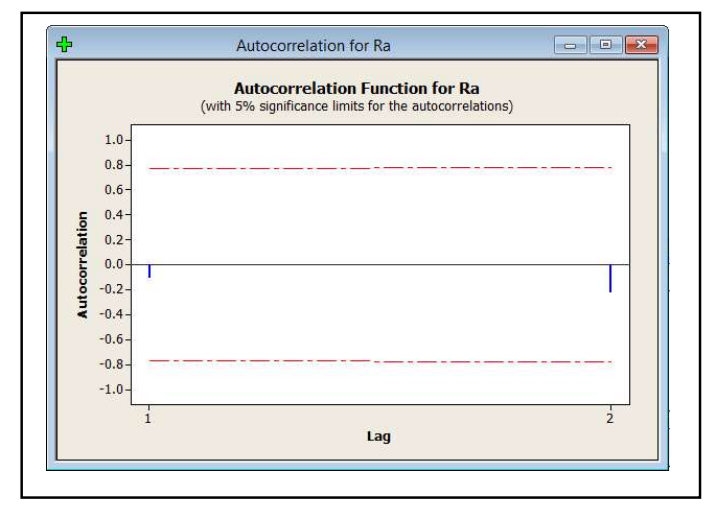

Fig. 5 ACF Plot

\subsubsection{Normal Distribution Test}

Normal distribution test was performed using Kolmogorov-Smirnov. The hypotheses used are: 
H0: Residual is normally distributed

H1: Residual is not normally distributed

$\mathrm{H} 0$ is rejected if the p-value is less than 0.05 .

Based on Figure 4 can be obtained p-value of $>0.150$, this value is greater than 0.05 . The conclusion of the hypothesis is that $\mathrm{H} 0$ is accepted. This means that the residual has met the requirements of a normal distribution.

\subsection{ANOVA Analysis}

After the data met the requirements of identical, independent and normally distributed assumptions, then an ANOVA analysis was carried out, to determine whether the process parameters had a significant effect on the response to the surface roughness of the milled workpiece. After being analysed by ANOVA, it was found that the F-value of each independent variable was compared with $\mathrm{F}(0.05)$ provided that if the $\mathrm{F}$-value $<$ F0.05 then $\mathrm{H} 0$ was accepted and if the F-value $>$

Table 4. ANOVA of Process Parameters on Surface Roughness

\begin{tabular}{|c|c|c|c|c|}
\hline Source & $\mathbf{N}$ & $\mathbf{V f}$ & Error & Total \\
\hline DF & 2 & 2 & 2 & 2 \\
\hline SeqSS & 0.26312 & 0.3451 & 0.06472 & 0.6729 \\
\hline Adj SS & 0.26312 & 0.3451 & 0.06472 & \\
\hline Adj MS & 0.13156 & 0.1725 & 0.01618 & \\
\hline F & 8.13 & 10.66 & & \\
\hline SS & 0.23076 & 0.3127 & & \\
\hline P & 0.039 & 0.025 & & \\
\hline $\begin{array}{c}\text { \% } \\
\text { Contribution }\end{array}$ & 34.29 & 46.47 & 19.23 & 100.00 \\
\hline
\end{tabular}

Based on the results of ANOVA analysis, the influence of process parameters on the surface roughness response can be explained as follows:

\subsubsection{Effect of spindle speed on surface roughness}

The hypothesis used in hypothesis testing using the $\mathrm{F}$ distribution is as follows:

$\mathrm{H} 0: \mathrm{N} 1=\mathrm{N} 2$

$\mathrm{H} 1: \mathrm{N} 1 \mathrm{~N} 2$

Conclusion: Fvalue $=8.13>\mathrm{F}(0.05 ; 2 ; 24)=3.4$ then $\mathrm{H} 0$ is rejected, meaning that there is a significant effect of spindle speed on surface roughness. In addition, a Pvalue of $0.039<0.05$ was also obtained, so it can be concluded that the spindle speed process parameter has a significant effect on surface roughness.

\subsubsection{Effect of feeding speed on surface roughness}

The hypothesis used in hypothesis testing using the F distribution is as follows:

$$
\mathrm{H} 0: \mathrm{Vf} 1=\mathrm{Vf} 2
$$

H1: Vf 1 Vf 2

Conclusion: Fvalue $=10.66>\mathrm{F}(0.05 ; 2 ; 24)=3.4$ then $\mathrm{H} 0$ is rejected, meaning that there is a significant effect of feeding speed on surface roughness. In addition, a P-value of $0.025<0.05$ was also obtained, so it can be concluded that the feed speed process parameter has a significant effect on surface roughness. Based on Table 4, the process parameters that have a statistically significant effect on the surface roughness response are feed speed and spindle speed. The biggest contribution to the surface roughness response was given by the feed speed, which was $46.47 \%$, followed by the spindle speed, which was $34.29 \%$. This is in line with the research conducted by Karkalos [16] and Izamshah [17] regarding the prediction of surface roughness in the milling process of Ti-6Al-4V ELI alloy materials. The results showed that the most influential factors on the surface roughness response were feed speed, cutting speed and depth of cut. Low surface roughness can be achieved with low feed speeds and high spindle speeds. The same thing was also achieved by Kiswanto [18], who conducted research on the effect of cutting parameters

on surface roughness in high-speed milling processes. The results of his research indicate that the spindle speed and feed motion have a significant effect on the surface roughness of the Titanium Ti-6Al-4V alloy material. The higher the spindle speed, the better the surface roughness will be.

\subsection{Wettability}

Another important property for the performance of an implant is the wettability or wettability of the surface. These criteria can influence the biological response around the implant. Furthermore, to observe the wettability of the surface, the contact angle between the liquid and solid surfaces is usually measured. Drops of $5 \mathrm{~L}$ distilled water on the specimens were photographed and analysed using the ImageJ application [18]. There are three different points that are dripped by water to confirm the count. Then, the final average value obtained is determined as the final measurement result. Total wetting will be experienced by a solid surface whose energy is higher than the tension of the liquid droplet, and the droplet spreads out in such a way that the contact angle is $0^{\circ}$. If the substrate has a relatively high surface energy, but lower than the surface tension of the liquid, the liquid will wet the solid surface and produce a contact angle of $0^{\circ}<\theta<90^{\circ}$ which means a hydrophilic surface or a high level of wettability. Otherwise, a larger contact angle will result from poor wetting which means the surface energy of the solid surface is low. A solid surface is claimed to have low wettability or hydrophobicity if the water droplets on its surface have a contact angle $>90^{\circ}$ which is classified as 
hydrophobic [19]. The results of the measurement of the contact angle of the titanium grade 2 specimen resulting from the milling process are shown in the following graph in Figure 4.6.

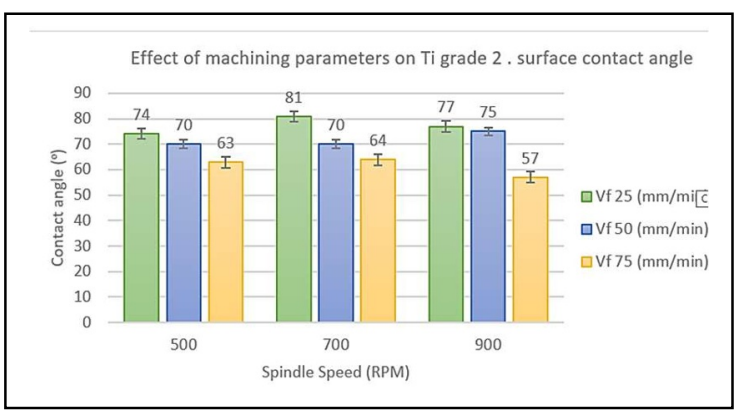

Fig 6. Effect of machining parameters on Ti grade 2. surface contact angle

The comparison of contact angles resulting from different machining parameters is shown in Figure 4.6. Based on the measurement results, all samples tend to show a decrease in the contact angle as measured by increasing the cutting speed. For all categories of spindle speed parameters, the cutting speed is directly proportional to the resulting contact angle. Overall, all specimens showed contact angle measurement results below $90^{\circ}$, which means hydrophilic. Several studies have shown that cell attachment tends to be enhanced by hydrophobic rather than hydrophilic implant surfaces [20]. However, Barman and Das in 2018 in their research, confirmed this response to be more specific, that the permanent implant surface must be hydrophobic while the semi-permanent implant must be hydrophilic. So it can be concluded that Titanium grade 2 material with this milling machining process can be used as an alternative to semi-permanent implant fabrication methods such as maxillofacial bone implants, bones of the fingers and toes, and others.

\section{References}

[1] V. C. Nguyen, T. D. Nguyen, and D. H. Tien, "Cutting Parameter Optimization in Finishing Milling of Ti-6Al-4V Titanium Alloy under MQL Condition using TOPSIS and ANOVA Analysis," Eng. Technol. Appl. Sci. Res., vol. 11, no. 1, pp. 6775-6780, 2021, doi: 10.48084/etasr.4015.

[2] M. S. Sisodiya and V. Bajpai, "An Insight: Machining of Titanium Alloys \& Associated Tool Wear," IOP Conf. Ser. Mater. Sci. Eng., vol. 1017, p. 12013, 2021, doi: 10.1088/1757899x/1017/1/012013.

[3] M. H. Ali Abotiheen, B. Khidhir, B. Mohamed, R. Balasubramanian, and A. Ataollahi Oshkour, Machining of Titanium Alloys: A Review, vol. 204. 2011.

[4] J. Menezes, M. A. Rubeo, K. Kiran, A. Honeycutt, and T. L. Schmitz, "Productivity Progression with Tool Wear in Titanium
Milling," Procedia Manuf., vol. 5, pp. 427-441, 2016, doi: https://doi.org/10.1016/j.promfg.2016.08.036.

[5] A. Iqbal et al., "Sustainable Milling of Ti-6Al$4 \mathrm{~V}$ : Investigating the Effects of Milling Orientation, Cutter's Helix Angle, and Type of Cryogenic Coolant," Metals, vol. 10, no. 2. 2020, doi: 10.3390/met10020258.

[6] M. Tools, “ $<130$ High Speed Milling Of Titanium Alloys Kaynaklarından Kaynak Çıkar.pdf>," vol. 3, pp. 131-140, 2008.

[7] F. I. Stratogiannis, N. I. Galanis, N. E. Karkalos, and A. P. Markopoulos, "Optimization of the Manufacturing Strategy, Machining Conditions, and Finishing of a Radial Impeller," Machines, vol. 8, no. 1, 2020, doi: 10.3390/machines 8010001 .

[8] P. J. Conradie, E. H. Uheida, G. A. Oosthuizen, and D. M. Dimitrov, "EVALUATING THE EFFECT OF MILLING STRATEGY ON PROCESS EFFICIENCY IN MACHINING TITANIUM ALLOYS - A COST MODELLING APPROACH," pp. 1-15, 2016.

[9] E. M. Rubio, A. Bericua, B. de Agustina, and M. M. Marín, "Analysis of the surface roughness of titanium pieces obtained by turning using different cooling systems," Procedia CIRP, vol. 79, pp. 79-84, 2019, doi: https://doi.org/10.1016/j.procir.2019.02.015.

[10] R. S, K. Lk, and K. Palanikumar, "Surface Roughness Analysis in Machining of Titanium Alloy," Mater. Manuf. Process., vol. 23, pp. 174-181, Feb. 2008, doi: 10.1016/s.matdes2004.05.008.

[11] A. Mufarrih, H. Istiqlaliyah, and M. M. Ilha, "Optimization of Roundness, $\{M R R\}$ and Surface Roughness on Turning Process using Taguchi-\{GRA\}," J. Phys. Conf. Ser., vol. 1179, p. 12099, Jul. 2019, doi: 10.1088/17426596/1179/1/012099.

[12] V. G. Umasekar, G. Msn, K. Rahul, S. Saikiran, and G. V Mowli, "Investigation of surface roughness in finish turning of titanium alloy Ti6Al-4V," ARPN J. Eng. Appl. Sci., vol. 12, pp. 5029-5034, Sep. 2017.

[13] A. Kumar and G. Sehrawat, "Investigation of Surface Roughness and Tool wear during turning of Titanium Alloy Grade 5 (Ti-6Al-4V) by using coated carbide tool and optimization of process parameters," IOP Conf. Ser. Mater. Sci. Eng., vol. 1033, no. 1, 2021, doi: 10.1088/1757899X/1033/1/012067.

[14] M. Wimmer et al., "The influence of the process parameters on the surface integrity during peripheral milling of Ti-6Al-4V:," tm - Tech. Mess., vol. 87, no. 11, pp. 721-731, 2020, doi: doi:10.1515/teme-2020-0052.

[15] J. Nithyanandam, S. LalDas, and K. Palanikumar, "Surface Roughness Analysis in Turning of Titanium Alloy by Nanocoated 
Carbide Insert," Procedia Mater. Sci., vol. 5, pp. 2159-2168, 2014, doi: https://doi.org/10.1016/j.mspro.2014.07.420.

[16] N. E. Karkalos, N. I. Galanis, and A. P. Markopoulos, "Surface roughness prediction for the milling of Ti-6Al-4V ELI alloy with the use of statistical and soft computing techniques," Measurement, vol. 90, pp. 25-35, 2016,

doi: https://doi.org/10.1016/j.measurement.2016.04. 039.

[17] R. Izamshah, B. Redzuwan, M. Aziz, and M. Kasim, "Comparative study of tool wear in milling titanium alloy (Ti-6Al-4V) using PVD and CVD coated cutting tool," Ind. Lubr. Tribol., vol. 69, May 2017, doi: 10.1108/ILT09-2016-0202.

[18] G. Kiswanto, A. Mandala, M. Azmi, and T. J. Ko, "The Effects of Cutting Parameters to the Surface Roughness in High Speed Cutting of Micro-Milling Titanium Alloy Ti-6Al-4V," in Engineering and Innovative Materials VIII, 2020, vol. 846, pp. 133-138, doi: 10.4028/www.scientific.net/KEM.846.133.

[19] R. T. Abrahão, V. Postal, J. Paiva, and R. Guardani, "Wettability study for pigmentary titanium dioxide," J. Coatings Technol. Res., vol. 10, Nov. 2013, doi: 10.1007/s11998-0139530-2.

[20] S. Becker, R. Merz, H. Hasse, and M. Kopnarski, "Solvent cleaning and wettability of technical steel and titanium surfaces," Adsorpt. Sci. Technol., vol. 34, no. 4-5, pp. 261-274, 2016, doi: 10.1177/0263617416645110. 